\title{
The Common Science Misconceptions in Indonesia Junior High School Students
}

\author{
Putri Anjarsari ${ }^{1^{*}}$ \\ ${ }^{1}$ Department of Science Education, Yogyakarta State University \\ Corresponding Author. Email: putri_anjarsari@uny.ac.id
}

\section{Keywords: misconceptions, junior high school, Indonesia students}

\begin{abstract}
Identifying and correcting the mistake that students make about science concept is very important. The main purpose of this article is to analyse some publications about common science misconceptions in some science topics in junior high schools. Misconceptions are erroneous perceptions of what is universally accepted. The misconception identification in this research is based on the descriptive research using some journal publications in Indonesia university which is held science education study program. Study found that : the concept of photosynthesis, respirations, the relationship of photosynthesis and respirations, force (action and reaction forces), and Newton laws are most frequently investigated as misconceptions of science. Students' interest and learning environments are some reasons of students' misconceptions.
\end{abstract}

C2018 JSER. Yogyakarta State University.

\section{INTRODUCTION}

Studies related to the students' missconceptions are being conducted seriously all over the world. Research on students' conceptions has proliferated in the last twenty years and enhanced our understanding about the preconceptions, misconceptions, and alternative conceptions that students bring with them to the classroom (Deshmukh \& Deshmukh, 2009). It is well accepted that misconceptions are common among students and it is crucial to overcome. Misconceptions are erroneous perceptins of what is universally accepted. Another term of misconceptions are understood as a misunderstanding of scientific concept (Svandova, 2014).

Some researcher advocate, therefore,that teachers should know common students misconceptions for the topic they teach (Hill, Schilling, \& Ball, 2015). Teachers who know their students' most common misconceptions are more likely to increase their students' science knowledge than teacher who do not (Sadler \& Sonnert, 2016). Based on those reasons, it is important for researchers and teachers to know what types of misconception usually occur in students' perceptions.

\section{METHODS}

The purposes of this article is to identify some common science misconceptions in Indonesia junior high school students. The misconception identification is based on the descriptive research using some journal publications in Indonesia university which is held science education study program.

\section{RESULTS}

Photosyntesis is one of important topics in biology and have many difficulty concepts. Identification of misconconception in photosynthesis concept should be conducted to define the suitable teaching and learning methodes. D. Ariandini, A. Anggraeni, and A. Aryani in 2013 studied about students' misconception by drawing analysis (Ariandini \& Anggraeni, 2013). Students on second grade at junior high school were used as subject in this study. Misconception identification was determined by students' drawing and interview. The result showed that, based on their drawing, there were 2,9\% students identified which held misconception. From the interview result, there 
were $35,2 \%$ students held a misconception, more than drawing analysis result. Students' misconception on photosynthesis concept were: the materials used in photosynthesis process, the products of photosynthesis process, and the location of photosynthesis occurred. The percentage of each misconception concept is shown in Tabe 1. Factor that made students' misconception because of students' itself (students' interest, recitative learning methodes, uncomplete information) and their environment.

The study of misconception in photosynthesis also conducted by G. A. D. Setiawati, I. B. A. Arjaya, and N. W. Ekayanti (2014). The research was conducted with 2 nd grade students in junior high schools (Setiawati, Arjaya, \& Ekayanti, 2014).

The author concluded that $42,96 \%$ students have a misconception in understanding the relation between some concepts in photosynthesis and respiration. There are 14 types of misconception in photosynthesis and respiration. The result is shown in Table 2.

The type of misconception number 4 and 8 is about material used in photosynthesis and respiration. The type of misconception number $1,2,5$, and 8 is about product of photosynthesis and respiration, and the number 6 is a misconception type about location of photosynthesis occurred. The other numbers are related to the process of photosynthesis and respiration.

Based on the two researches above (table 1 and table 2), the common science misconception is about photosynthesis and respiration, especially the concept of material, product, location, and process of photosynthesis and respiration.

Researches of students' misconceptions about photosynthesis and plant respiration are widely studied topic worldwide. In 2009, Deshmukh \& Deshmukh published the research about that. Research shows that a common misconception found among the students is that respiration and breathing are the same process. However, terms respiration refers to cellular metabolism and breathing refers to the inhalation and exhalation of air.

Another common misconception is that photosynthesis takes place during the day whereas respiration takes place only at night and in plants (Deshmukh \& Deshmukh, 2009). Another research was conducted by K. Svandova in 2014.This research shows that many students do not even understand the fundamental concept that photosynthesis and plant respiration are related, mutually connected physiological functions (Svandova, 2014)

Table 1. Percentage of missconception in photosynthesis concepts (Ariandini \& Anggraeni, 2013)

\begin{tabular}{llc}
\hline No & \multicolumn{1}{c}{ Concept } & Percentage \\
\hline 1 & The materials used in photosynthesis process & $17,65 \%$ \\
\hline 2 & The products of photosynthesis process & $47,05 \%$ \\
\hline 3 & The location of photosynthesis occurred & $35,30 \%$ \\
\hline
\end{tabular}

Table 2. Types of misconception list experienced by 2nd grade of junior high schools students in denpasar in the concept of photosynthesis and respiration of plant (Setiawati et al., 2014)

\begin{tabular}{ll}
\hline No & \multicolumn{1}{c}{ Misconceptions } \\
\hline 1 & $\begin{array}{l}\text { Oxygen is a waste gas from photosynthetic process that are not used in the process of respiration } \\
\text { in plants }\end{array}$ \\
\hline 2 & Plants produce oxygen in the process of respiration \\
\hline 3 & Respiration in plants occurs when there is no light \\
\hline 4 & Photosynthesis in plants can occur even when there is no light \\
\hline 5 & The most important benefit of photosynthesis for plants is to produce energy \\
\hline 7 & Respiration of plants only occurs in the leaves because the leaves contain stomata \\
\hline 8 & Respiration in plants is a process of carbondioxyde and oxygen exchange through stomata \\
\hline 9 & Plants require carbondioxyde and produce oxygen \\
\hline 10 & Respiration in plants is the process of making food from water and oxygen \\
\hline 11 & $\begin{array}{l}\text { Respiration in plants is a process of gas exchange, in which oxygen is taken and carbondioxyde } \\
\text { is released }\end{array}$ \\
\hline 12 & $\begin{array}{l}\text { Plants doing respiration process when there is no light, while animals doing this process all of the } \\
\text { time }\end{array}$ \\
\hline
\end{tabular}




\begin{aligned} \hline 13 & Plants doing respiration at night since they can not getting enough energy from photosynthesis \\ \hline 14 & $\begin{array}{l}\text { Animals doing respiration all of the time because they can not afford photosynthesis to gain } \\ \text { energy }\end{array}\end{aligned}$

Table 3. Students' misconception in the topic of force and Newton laws

\begin{tabular}{cl}
\hline No & \\
\hline 1 & The definition of force \\
\hline 2 & The force in motorcycle that moves on the road \\
\hline 3 & $\begin{array}{l}\text { The force that works on the ruler so that can pulls small pieces of paper after being rubbed on dry } \\
\text { hair }\end{array}$ \\
\hline 4 & The force that works in "tug of war" \\
\hline 5 & The cause of moving object \\
\hline 6 & The cause of motion object to stop \\
\hline 8 & The use of wheels on car (related to force) \\
\hline 9 & The inertia of object \\
\hline 10 & The concept of force balance \\
\hline
\end{tabular}

Based on journal and article exploration, another topic of students' misconception are force and Newton laws. I.W.G. Wiradana in 2012 studied about how to overcome students' misconception about force and Newton laws (Wiradana, n.d.). He studied students' misconceptions before and after the instructional processes. The students' misconceptions were obtained from the analysis of the students' answers on their concept understanding by asking them to provide reasons behind their answers. The results indicated that there were various types of misconception arouse from the students' environment interaction and instructional process or the previous instructional process. The detail result is shown in Table 3 (Wiradana, n.d.). I.W.G. Wiradana change of SMP students through creating a real problem based constructivist learning environment. However, some misconception types were found increasing.

The findings of misconceptions in Newton's force and law above can be used as a reference by teachers to manage science learning in junior high. The above resistant misconceptions are important in the emphasis of learning because learning can contribute to misconceptions. Teachers need to be prudent in managing learning, especially in looking at class discussions and giving feedback.

Another publication about students' misconception in the topic of Newton law is conducted by U. Setiya, R. Novi Siti Nur, and S. Irma Rahma in 2012(Setiya, Novi Siti Nur, \& Irma Rahma, 2012). The type of misconception usually occurs are: students can not determine the action reaction force pairs, there is no force acting on a stationary object, the object of small mass have greater inertia, objects moving with constant velocity has a constant acceleration.
There is a limited publication (journal and article ) about science misconception in Indonesia. The exploration analysis from online journals in some University in Indonesia shows that the common science misconception in Indonesia junior high school students are the topic of photosynthesis, respiration, Newton's laws, and Force.

Overcoming students' misconception can be conducted by several strategies, they are: 1) teacher preparation, 2) use of innovative techniques, 3) curriculum modification, 4) development of enrichment material (Deshmukh \& Deshmukh, 2009). Identifying students' pre-conception is also crucial for correcting misconception. Students' preconception can be obtained by literature study,diagnostic test, observation, concept map, and interview.

\section{CONCLUSION}

Misconceptions are erroneous perceptions of what is universally accepted. Study found that the concept of photosynthesis, respirations, the relationship of photosynthesis and respirations, force (action and reaction forces), and Newton's laws are most frequently investigated as misconceptions of science.

\section{REFERENCES}

Ariandini, D., \& Anggraeni, S. (2013). Identifikasi Miskonsepsi Siswa Smp Pada Konsep Fotosintesis Melalui Analisis Gambar. Jurnal Pengajaran Matematika Dan Ilmu Pengetahuan Alam, 178-184. Retrieved from http://journal.fpmipa.upi.edu/index.php/jpmip a/article/view/36

Deshmukh, N. D., \& Deshmukh, V. M. (2009). A 
Putri Anjarsari / JSER 2018, 2(1), 24

study of students' misconceptions in biology at the secondary school level. Proceedings of 6th International Conference on Hands on Science.

Hill, H. C., Schilling, S. G., \& Ball, D. L. (2015) Developing Measures of Teachers Mathematics Knowledge for Teaching. The Elementary School Journal, 105(1), 11-30.

Sadler, P., \& Sonnert, G. (2016). Understanding Misconceptions - Teaching and Learning in Middle School Physical Science. American Educator, 26-32.

Setiawati, G. A. D., Arjaya, I. B. A., \& Ekayanti, N. W. (2014). Identifikasi Miskonsepsi Dalam Materi Kelas Ix Smp Di Kota Denpasar. Jurnal Bakti Saraswati, 3(2), 1-15.

Setiya, U., Novi Siti Nur, R., \& Irma Rahma, S. (2012). Efektivitas Penerapan Metode Peer
Insruction with Structured Inquiry dengan Menggunakan Prototype media Berbasis CMAPTOOLS untuk Mengurangi Miskonsepsi Siswa. Jurnal Pengajaran Matematika Dan Ilmu Pengetahuan Alam, 17(1), 60-68.

Svandova, K. (2014). Secondary school students' misconceptions about photosynthesis and plant respiration: Preliminary results. Eurasia Journal of Mathematics, Science and Technology Education, 10(1), 59-67. https://doi.org/10.12973/eurasia.2014.1018a

Wiradana, I. W. G. (n.d.). Pengubahan miskonsepsi siswa smp melalui penciptaan lingkungan belajar konstruktivis berbasis masalah nyata. 